\title{
Hoopers' List of the Birds Of the Somme District
}

\section{A REVIEW BY MAURICE STREET, NIPAWIN}

I am in receipt of "A Preliminary List of the Birds of the Somme District, Saskatchewan," edited and mimeographed by Dr. C. Stuart Houston. The list is to be distributed by Dr. Stuart Houston, Box 279, Yorkton, Sask., at twenty-five cents a copy.

Somme is located on the Canadian National Railway and on Highway No. 3, 50 miles south-east of Tisdale. It is some 100 miles N.N.W. of Yorkton, and some 165 airline miles N.N.E. of Regina.

The Somme district lies entirely within the Canadian Life Zone - the only exception being several small "islands" of Transition Zone in the Piwei Hills. This onetime heavily forested area, through fires and clearing by the settlers is now reduced to about $20 \%$, and the remainder is fertile agricultural land, thus the settled areas now appear very similar to the "aspen parkland" area of the Northern Transition Zone. To the east of Somme lies the Porcupine Forest Preserve, heavily wooded with American Aspen, Balsam Poplar, White and Black Spruce, Tamarack, Birch and Balsam Fir. The main bodies of water are the Piwei Lakes. The area is drained by the Red Deer, Copeau and Etomami Rivers.

Ronald and Donald Hooper, twins, in their early twenties, have compiled a rather amazing list when it is realized. As they state in the foreword: "We were not greatly interested in Nature until we took a correspondence course in Taxidermy. In the fall of 1950 we mounted several birds that we were unable to identify, so bought some bird books. Then our interest quickly grew ..." The list records 206 species, plus four hypothetical species. Of the 206 species, 153 have been substantiated by collecting and mounting. These have been indicated in the list. Also 88 species have been found to breed by the discovery of the nests, plus an additional 8 species that have been noted with flightless young. Migration dates are also listed, both spring and fall, of most of the common species. A few early observations are also given in the list, dating back to 1920 . These were made by Mr. W. A. Black, a farmer of the Somme District. The value of these observations are distracted by $\mathrm{Mr}$. Black's lack of keeping written records.

Ronald and Donald Hooper should be highly commended for this fine piece of work, for without contact with other ornithologists, except by correspondence, the list is a notable achievement and will be recognized as an accurate piece of scientific observation.

The list is comprised of a frontispiece, two pages of introduction and treatment, a map of the area, and eleven closely typed sheets of text.

For the most part the species dealt with are to be expected in this region, however there are several which are worthy of special comment.

BLUE GOOSE - Several large flocks migrating on September 22 and 23.

HOODED MERGANSER - A specimen collected, and a flock noted on the Piwei river, early in October, 1952. These are two species that are only rarely observed elsewhere in Saskatchewan.

We are surprised to learn that the PEREGRINE FALCON is a common fall migrant and that the GYRFALCON is regularly seen, but uncommon in early winter.

WINTER WREN - This rare little wren was seen October 3, 1951. A rounded nest of moss was found on a spruce branch in January, 1954, which contained a wren wing primary that Mr. Godfrey, of the $\mathrm{Na}$ tional Museum, Ottawa, reported as apparently that of a Winter Wren. 


\section{Hoopers' Museum in Farm Granary}

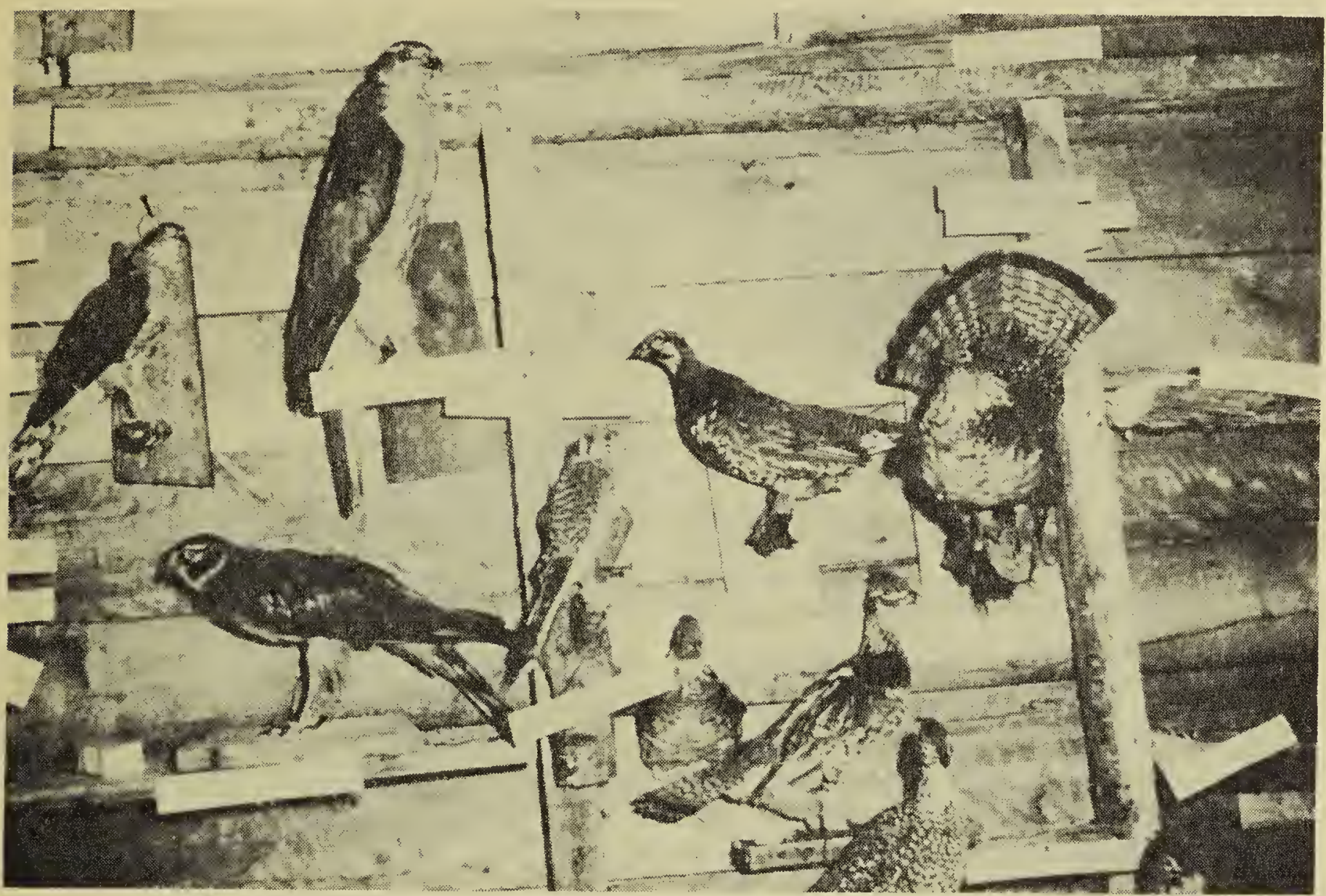

-Photo from Kodachrome by Dr. Stuart Houston.

The 153 species of birds collected by the Hoopers in the past four years are on display in a granary near their home.

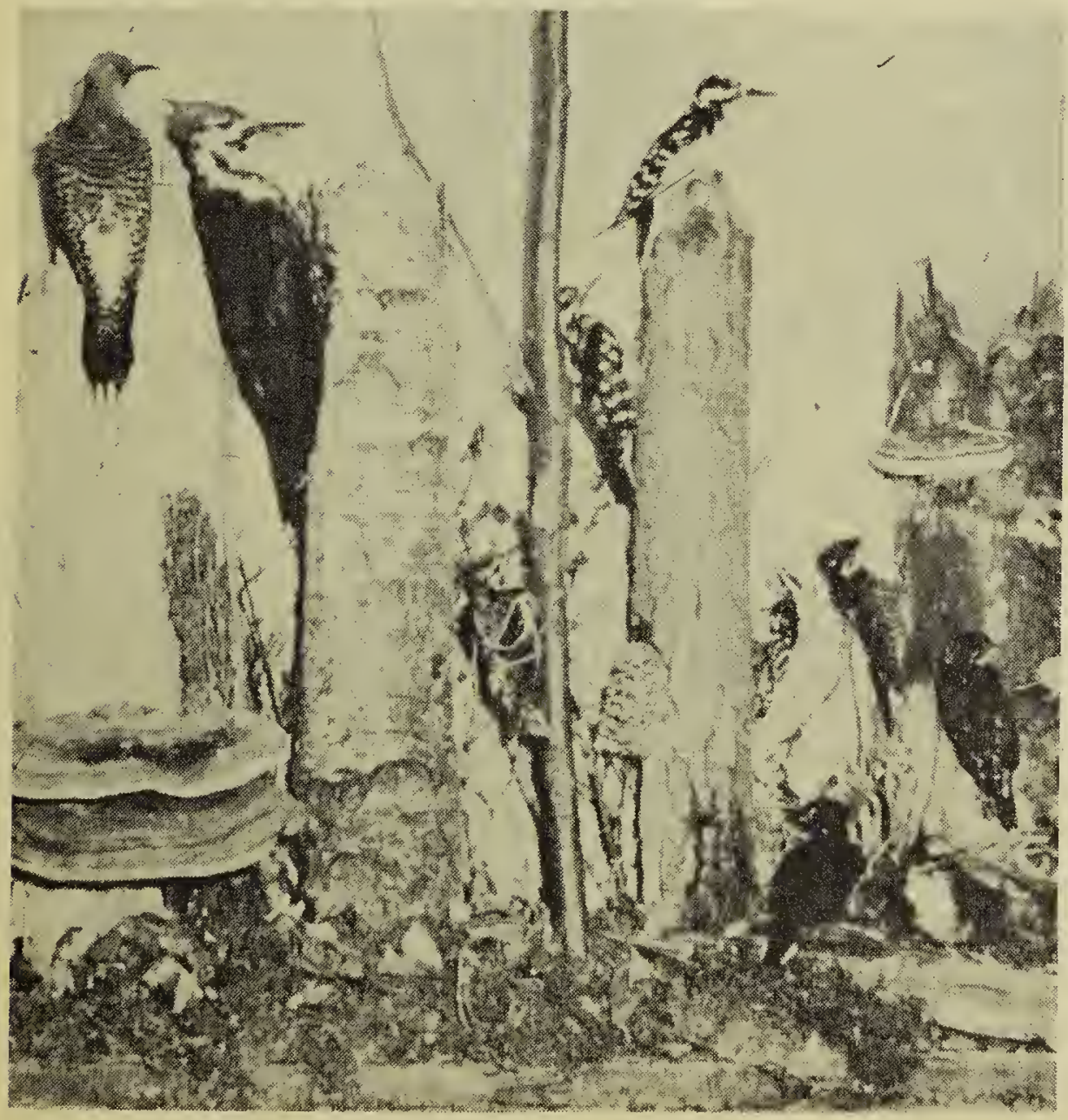

\section{Woodpecker} Habitat Group

This lovely group of seven species of Woodpeckers, collected by the Hooper twins on their farm, adorns the Hooper living room. 